\title{
Brine, englacial structure and basal properties near the terminus of McMurdo Ice Shelf, Antarctica
}

\author{
S. CAMPBELL, ${ }^{1,2}$ Z. COURVILLE, ${ }^{1}$ S. SINCLAIR, ${ }^{1}$ J. WILNER ${ }^{3}$ \\ ${ }^{1}$ U.S. Army-CRREL, Hanover, New Hampshire, USA \\ E-mail: seth.w.campbell@gmail.com \\ ${ }^{2}$ University of Maine, Orono, Maine, USA \\ ${ }^{3}$ Middlebury College, Middlebury, Vermont, USA
}

\begin{abstract}
We collected $\sim \mathbf{1 3 0 0} \mathrm{km}$ of ground-penetrating radar profiles over McMurdo Ice Shelf, Antarctica, using frequencies between 40 and $400 \mathrm{MHz}$ to determine extent, continuity and depth to the brine. We also used profiles to determine meteoric ice thickness and locate englacial features, which may suggest ice shelf instability. The brine extends 9-13 km inland from the ice shelf terminus and covers the entire region between Ross, White and Black Islands. Jump unconformities and basal fractures exist in the brine and ice shelf, respectively, suggesting prior fracturing and re-suturing. One $100 \mathrm{MHz}$ profile, the most distal from the ice shelf edge while still being situated over the brine, simultaneously imaged the brine and bottom of meteoric ice. This suggests a negative brine salinity gradient moving away from the terminus. The meteoric ice bottom was also imaged in a few select locations through blue ice in the ablation zone near Black Island. We suggest that brine, sediment-rich ice and poor antenna coupling on rough ice attenuates the signal in this area. When combined with other recent mass-balance and structural glaciology studies of MIS, our results could contribute to one of the most high-resolution physical models of an ice shelf in Antarctica.
\end{abstract}

KEYWORDS: glacier geophysics, glacier mapping, ground-penetrating radar, ice/ocean interactions, ice shelves

\section{INTRODUCTION}

The McMurdo Ice Shelf (MIS) in West Antarctica has experienced noteworthy retreat and re-advance over the past 70 years. As recently as 1947, the MIS fractured or retreated enough to allow seals to migrate between air pockets and reach White Island, a landmass $18 \mathrm{~km}$ inland from the current ice shelf front (Gelatt and others, 2010). Despite the migrated seal population, no physical evidence has been found within the ice shelf to confirm this retreat or fracturing. However, surface melting on MIS and broader Antarctic ice shelf instability has been of scientific concern since the 1960s (Stuart and Bull, 1963; Paige, 1968; Kovacs and Gow, 1975; Klokov and Diemand, 1995). A heightened level of concern for the long-term future of the MIS, both from a logistical and scientific standpoint, stems from recent findings of instability within the West Antarctic Ice Sheet and the surrounding ice shelves (e.g. Joughin and others, 2014; Rignot and others, 2014). Additional observations point to possible instability including basal crevassing and subglacial water channeling, (Sergienko and Hulbe, 2011; Luckman and others, 2012), calving events such as the B-15 break-up event that could influence ice pack around the MIS (BRP, 2012), and recent melting near Pegasus Runway (Shoop and others, 2013). Well-documented impacts of ice shelf failure include acceleration and thinning in up-glacier regions (e.g. Scambos and others, 2004). Logistically, the seriousness of this issue is summarized by the Blue Ribbon Panel Study (BRP, 2012), which indicates that an interruption of MIS runway operations could be considered a 'single-point failure' that would jeopardize both the USA and New Zealand Antarctic programs.
Initial ground-penetrating radar (GPR) surveys of MIS near its terminus by Kovacs and Gow (1975) revealed step discontinuities within the brine layer that were interpreted as evidence of prior large-scale fractures or calving events. Morse and Waddington (1994) imaged similar features within the brine horizon and argued that they were evidence of lateral motion (brine retreat toward the ice front in this instance) in response to ice front fracture events. Grima and others (2016) used extensive airborne radar centered at $60 \mathrm{MHz}$ to develop a broad understanding of the brine extent, snow, firn and ice conditions of MIS. They show a trend of decreasing snow and firn thickness from Ross Island toward Black Island and an inverse relationship in density, with a blue ice ablation area existing toward Black Island. They attribute these thickness and density differences to wind re-deposition of accumulation away from Black Island and spatial variations in snowfall with higher rates near Ross Island. Unfortunately, the low frequency and wide footprint of airborne radar results in low vertical $(\sim 5.6-9.5 \mathrm{~m})$ and horizontal (200-400 m) resolutions, which are unable to resolve smaller englacial structures near the MIS terminus. Arcone and others (2016) used robot-towed GPR to show substantial structural complexities located upstream of White Island, in high-resolution. Their region of interest was part of a $\sim 5 \mathrm{~km}$ wide by $\sim 60 \mathrm{~km}$ long shear zone created by a velocity gradient associated with buttressing from Minna Bluff and White Island. The shear zone consists of $\sim 150 \mathrm{~m}$ of meteoric ice and 20-30 $\mathrm{m}$ of stratified marine ice at the ice shelf base. Buried surface crevasses to $30 \mathrm{~m}$ depth and bottom crevasses or rifts, both caused by a combination of tensile and shear 
stress, are prevalent in profiles collected by Arcone and others (2016).

Our interest originated from determining what happened to these surface and basal crevasses down glacier and toward the terminus of MIS. Likewise, an apparently stable surface rift also exists near the MIS terminus, which further stimulated our interest in determining if other englacial features existed which may contribute to future ice shelf instability. Herein, we describe a systematic GPR survey of MIS conducted in November-December 2015 near its terminus to quantify meteoric ice thicknesses, depth and extent of the brine horizon, and to locate any structural features within the near-terminus ice shelf, such as large-scale basal fractures, subglacial channels, or brine fractures, which could indicate or affect MIS stability.

\section{STUDY SITE}

The McMurdo Ice Shelf within McMurdo Sound is a $1000 \mathrm{~km}^{2}$ region, which is separated from the broader Ross Ice Shelf by Ross Island (Fig. 1). The area is bound by Ross Island's Hut Point, White Island, Black Island and Brown Peninsula. Most of the glacier ice that flows into McMurdo Sound originates from the eastern Ross Ice Shelf, curling around White Island from the south and buttressed by Hut Point to the north. Some debris-rich and ablating ice flowing toward the MIS terminus also originates from the Black Island and Brown Peninsula regions (Glasser and others, 2014). The ice shelf currently terminates in front of Scott Base in a north-south orientation that is perpendicular to Hut Point shoreline. Ice velocities transition from 260 to $380 \mathrm{~m} \mathrm{a}^{-1}$ within the shear zone upstream of White Island (Arcone and others, 2016) to $100-230 \mathrm{~m} \mathrm{a}^{-1}$ between Hut Point and White Island. The slower velocities within McMurdo Sound are attributed to buttressing of Hut Point which we suggest causes compression and therefore re-suturing of rifts created by the velocity gradient up-glacier of White Island and Mina Bluff.

\section{METHODS}

We used a SIR-4000 GPR control unit coupled with a model 3200 MLF Multiple (Adjustable) Low-Frequency Antenna at $40 \mathrm{MHz}$, a model $3207100 \mathrm{MHz}$ antenna, a model 5106 $200 \mathrm{MHz}$ antenna and a model $50400400 \mathrm{MHz}$ antenna, each unit manufactured by Geophysical Survey Systems Incorporated (GSSI). One $40 \mathrm{MHz}$ profile was collected along Pegasus Road and one $200 \mathrm{MHz}$ profile was collected along the South Pole Traverse Road from the ice shelf front to the shear zone. These two profiles were repeated with the 100 and $400 \mathrm{MHz}$ antennas. The remaining eleven $\sim 20$ $45 \mathrm{~km}$ long profiles, spaced $\sim 5 \mathrm{~km}$ apart in a radial pattern and perpendicular to the ice shelf front toward White or Black Island, were collected with both the 100 and $400 \mathrm{MHz}$ antennas. Seven other profiles were collected parallel to the ice shelf front and roughly perpendicular to the radial profiles with the 100 and $400 \mathrm{MHz}$ antennas to develop a pseudo 3-D structure map of the MIS. In total, $\sim 1300 \mathrm{~km}$ of GPR profiles were collected covering the $1000 \mathrm{~km}^{2}$. Profiles were collected via snowmobile travelling

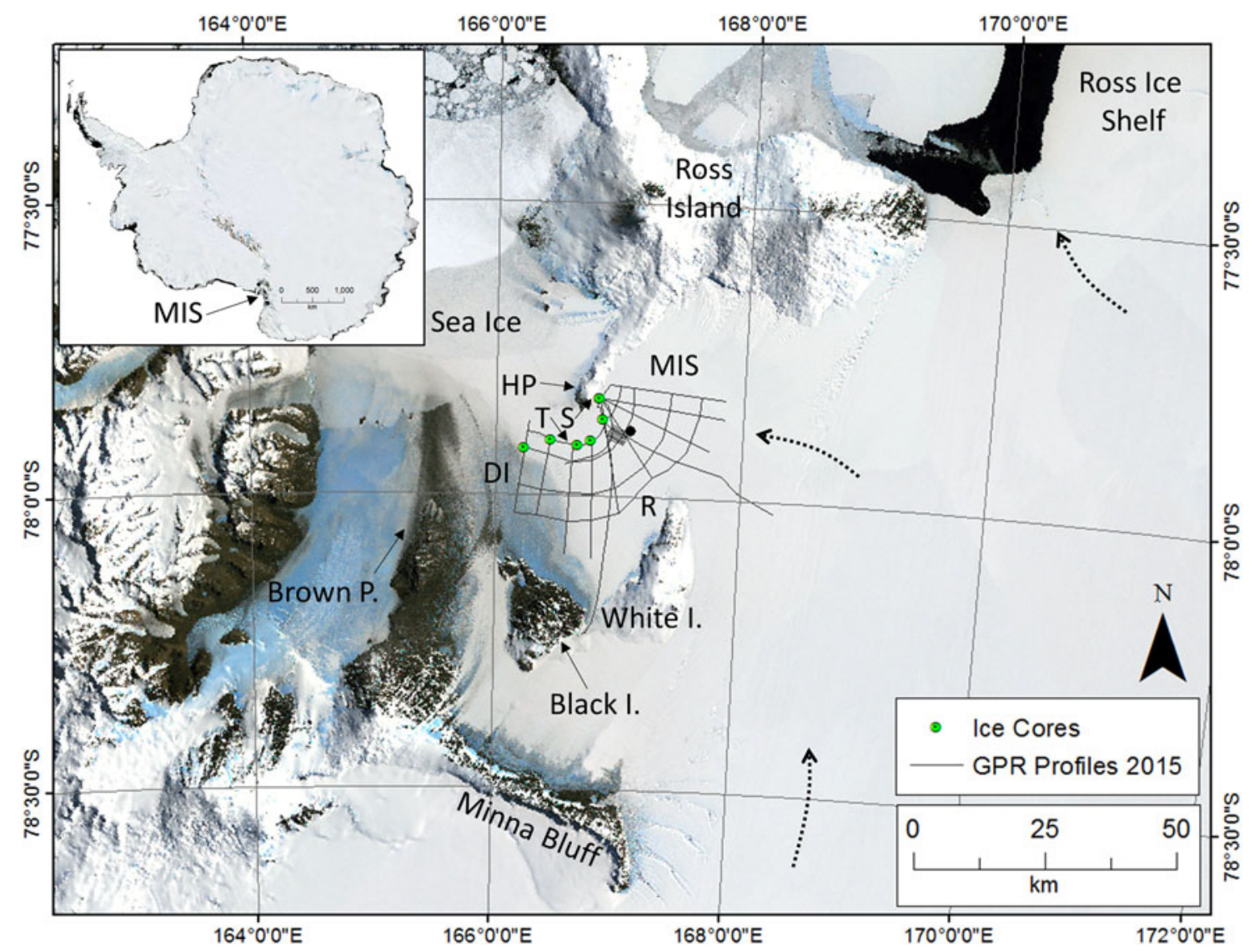

Fig. 1. Landsat image of MIS showing major features including its terminus location (T), White, Black and Ross Islands, Brown Peninsula, Minna Bluff, Hut Point (HP), Scott Base (S), debris-rich ice (DI), rifts formed by White Island (R) and general ice flow directions (black dotted arrows). Ice core locations (green dots) and GPR profiles (black lines) collected in 2015 are also shown. 
at $\sim 5-15 \mathrm{~km} \mathrm{~h}^{-1}$ with $24 \mathrm{scans} \mathrm{s}^{-1}$ resulting in traces being recorded every $\sim 10 \mathrm{~cm}$ in horizontal distance. Scans were recorded for 1400-2500 ns two-way travel time (TWTT) with 2048-4096 samples scan $^{-1}$; this sampling rate provides 10-19 samples $\mathrm{m}^{-1}$ which is adequate to maintain a smooth waveform given the frequencies used. For example, a $100 \mathrm{MHz}$ wavelength in ice is $\sim 1.69 \mathrm{~m}$ with a $\sim 10 \mathrm{~ns}$ period. A smooth waveform will be generated when sample rates are $\geq 10$ samples per period, or $\geq 1$ sample $\mathrm{ns}^{-1}$ in this case. At 4096 samples scan ${ }^{-1}, 2500 \mathrm{~ns}$ TWTT reaches ice depths of $\sim 211 \mathrm{~m}$ based on a relative permittivity $(\dot{\varepsilon})$ of glacier ice (3.1) and associated wave velocity $(0.169 \mathrm{~m}$ $\mathrm{ns}^{-1}$ ) resulting in $\sim 19$ scans $\mathrm{m}^{-1}$ or $>1$ sample $\mathrm{ns}^{-1}$. We report TWTT of each profile to minimize velocity and depth assumptions. We used faster towing speeds $(\sim 15 \mathrm{~km}$ $\mathrm{h}^{-1}$ ) with higher frequency antennas $(200$ and $400 \mathrm{MHz})$ due to the shallow depth and strong continuous brine horizon acting as the primary reflector. Profiles collected to image the ice shelf bottom (40 and $100 \mathrm{MHz}$ ) were collected more slowly at higher sampling rates to assure stratigraphy was also imaged. Processing of each GPR profile included time-zero correction, band pass filtering and stacking.

We initially planned use of the 100 and $200 \mathrm{MHz}$ antennas to assess basal ice shelf conditions. Based on a $\dot{\varepsilon}$ of ice (3.1), 100 and $200 \mathrm{MHz}$ wavelengths $(\gamma)$ in ice (1.7 and $0.85 \mathrm{~m}$, respectively), and assuming $1 / 2 \gamma$ is required to distinguish adjacent horizons, these two antennas have corresponding vertical resolutions of $\sim 86$ and $\sim 44 \mathrm{~cm}$ (e.g. Woodward and Burke, 2007). We planned to use the $400 \mathrm{MHz}$ antenna to assess near-surface features and the brine horizon due to its higher vertical resolution at $\sim 22 \mathrm{~cm}$ using the same $1 / 2 \gamma$ assumption. In regions where the highly conductive brine layer infiltrates MIS and reduces GPR penetration (Clough, 1973; Morey and Kovacs, 1982; Kovacs and others, 1982a, b; Arcone and others, 1994; Arcone, 1996), we rely on shallow stratigraphy and brine layer discontinuities to indicate potential fracture locations. We also attempted to use the $40 \mathrm{MHz}$ antenna (4.3 $\mathrm{m} \gamma$ at $\dot{\varepsilon}=3.1$ or $\sim 2.2 \mathrm{~m}$ vertical resolution based on $1 / 2 \gamma$ ) to penetrate the brine horizon and image the ice shelf bottom near its terminus and transition to sea ice. Profiles were geo-referenced using a Trimble 5700 Rover with a Zephyr Geodetic GPS antenna (1-3 m spatial accuracy). Following Arcone and others (1994), our interpretation of horizons or reflections within radar profiles, in part, comes from a waveform polarity analysis of the first three half cycles, resulting from interfaces between two materials with $\dot{\varepsilon}$ contrasts. That is, a positive $(+-+)$ triplet suggests that the deeper layer or target has a higher $\dot{\varepsilon}$ than the overlying layer, and a negative $(-+-)$ triplet suggests that the deeper layer or target has a lower $\dot{\varepsilon}$ (Fig. 2). Examples of each scenario are dry firn over the brine $(+-+)$, or firn over a crevasse $(-+-)$.

Ground-truth of the brine horizon imaged using GPR were provided from six cores drilled near the ice shelf edge using a hand-powered SIPRE (Snow Ice and Permafrost Research Establishment) Corer with a $7.5 \mathrm{~cm}$ diameter, $1 \mathrm{~m}$-long core barrel, at locations close to the ice shelf edge (Fig. 3; Table 1). Core lengths ranged between 6 and $15 \mathrm{~m}$ and coring was terminated once the brine horizon was reached. We stopped coring and rapidly extricated the corer upon reaching this horizon because we were concerned with water from the brine freezing our core barrel in place. This horizon was typically distinguished immediately by an obvious wet and saline layer within the core. Each core was processed for stratigraphy, density, salinity and conductivity at $10 \mathrm{~cm}$ resolution to confirm that the brine horizon was reached (Fig. 4). Stratigraphy was recorded in the field and imaged using a near-infrared (NIR) digital camera (Fig. 5). The density was determined gravimetrically using a digital balance to measure mass, and digital calipers to measure the diameter and lengths of core sections. Cores were bagged, melted and allowed to reach a temperature equilibrium. Salinity, conductivity and temperature of each sample at the time of measurement were determined using a YSI Pro Series salinity/conductivity probe. The probe was rinsed in fresh water between each measurement.

Meteoric ice bottom depths in GPR profiles were estimated using cold glacier ice velocities $(\dot{\varepsilon}=3.1 ; v=$ $0.169 \mathrm{~m} \mathrm{~ns}^{-1}$ ) where velocity $v=c / \sqrt{\hat{\varepsilon}}$ and $c$ represents the speed of light in a vacuum. Kovacs and others (1993) define a relationship between $\dot{\varepsilon}$ and density in polar firn such that precise depth calculations can be made, assuming a depth-density profile is known. However, due to the vast expanse of terrain covered by this survey, limited potential depth calibration except for near the terminus to the brine horizon by our shallow cores, and lack of common midpoint GPR surveys for depth calibration, we instead

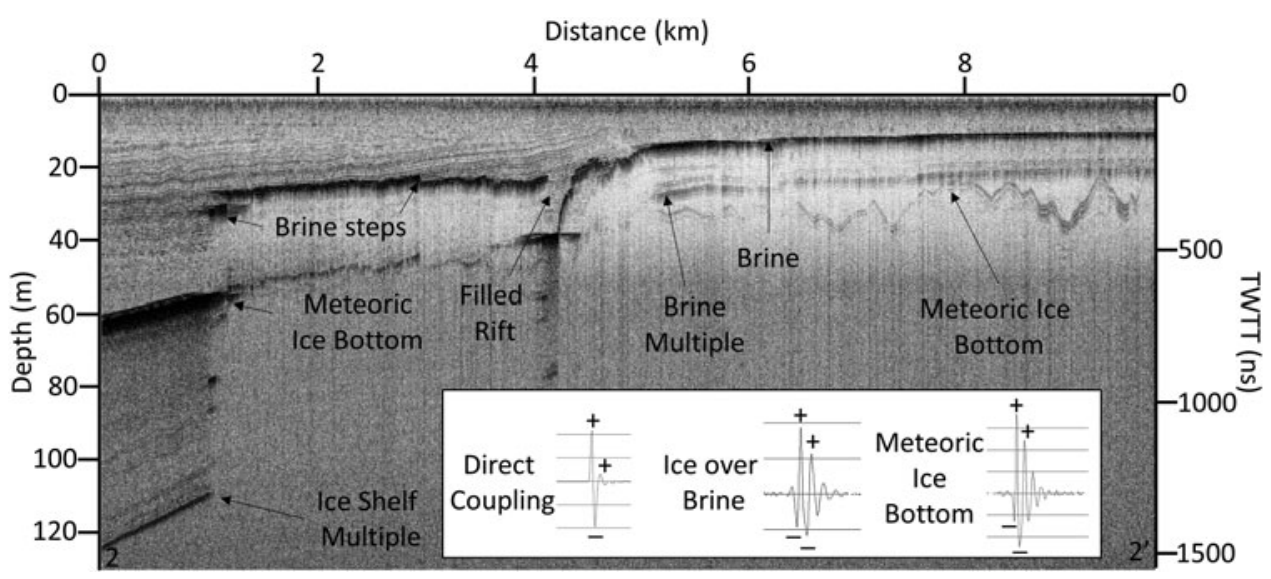

Fig. 2. $100 \mathrm{MHz}$ GPR profile showing the brine horizon and bottom of meteoric ice. This profile was the most distal, collected parallel to the ice shelf terminus (i.e. North to South) in this study. Note the rift, which was likely initiated due to buttressing of White Island as ice flowed around the corner, now filled with surface conformable stratigraphy (see Fig. 1 for location). The figure also shows the actual wave triplet responses for the direct coupling, ice over brine and meteoric ice bottom in the above profile near $6.5 \mathrm{~km}$ distance along the $x$-axis. 


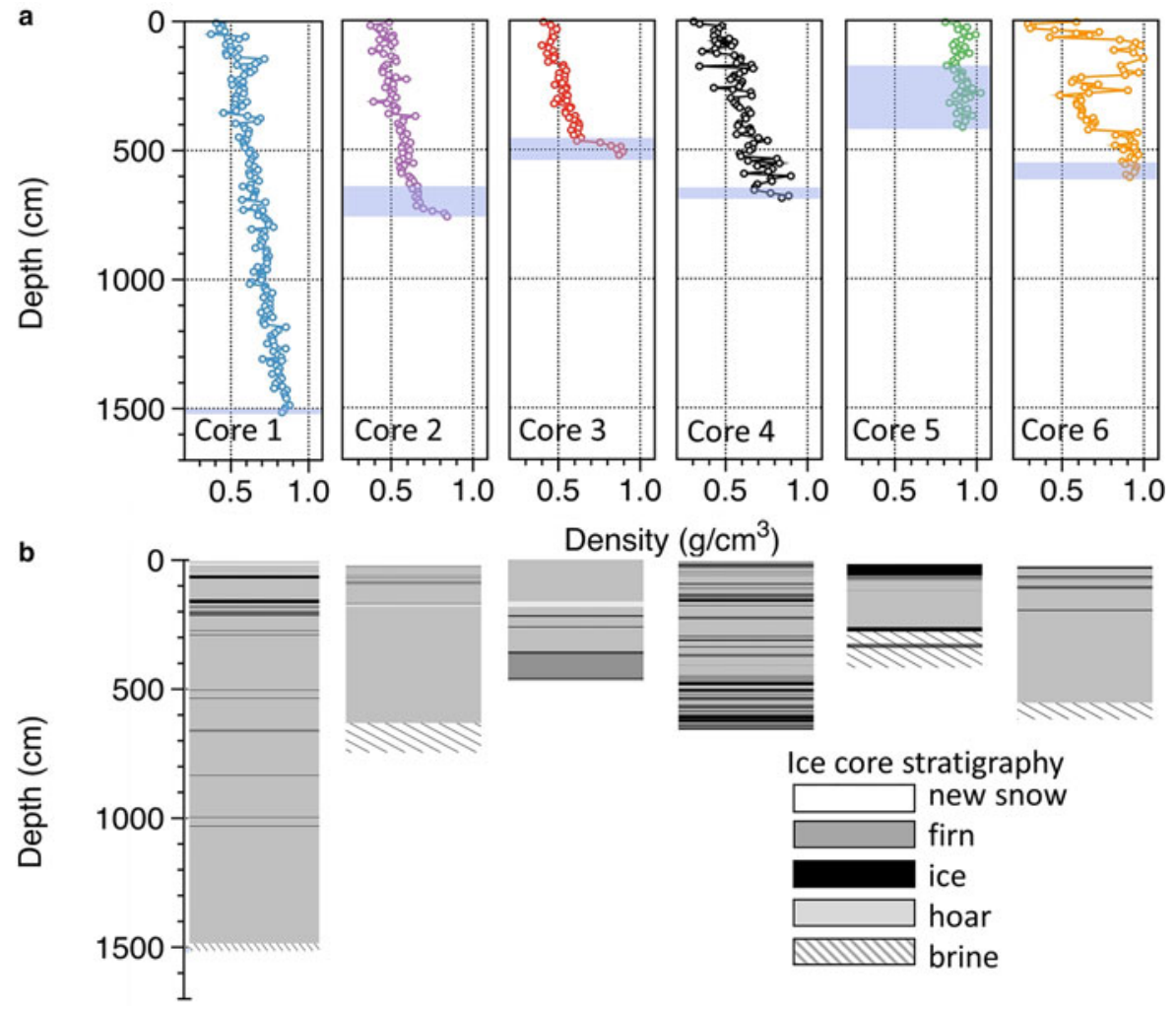

Fig. 3. Density (a) and stratigraphy (b) profiles of shallow firn and ice cores collected from MIS. (a) Density plot denoting discrete measured samples in $10 \mathrm{~cm}$ intervals and blue band indicating the brine horizon noted within each core through associated conductivity measurements of each core sample ( $0.1 \mathrm{ppt}$ resolution). (b) Core logs representing stratigraphy of each core. High densities at the bottom of the core are due to unfrozen brine creating a wet, slushy layer in the firn.

assume a cold ice velocity for shelf bottom depth calculations. Given the survey depths, small ratio of firn (variable density) to ice, and brine horizon influence, we expect depth calculation uncertainties in the range $5-10 \%$. We assume depth to the brine horizon based on a $\dot{\varepsilon}$ of 2.2 $\left(v=0.173 \mathrm{~m} \mathrm{~ns}^{-1}\right)$ and the fact that brine infiltration is controlled, in part, by permeability of the firn (e.g. Grima and others, 2016).

\section{RESULTS \& DISCUSSION}

\section{Ice and firn cores}

Table 1 summarizes the physical properties of the six ice cores, with detailed stratigraphy of the cores illustrated in Figs 4 and 5. Salinity indicated the overall presence of brine, and the maximum salinity recorded is indicative of how deep into the brine layer each core was drilled. Cores 1,2 and 5 were drilled well into the brine layer, while
Cores 3 and 4 only extended into the top portion of the brine. Core 5 was drilled in a blue ice area which appears to contain a diffuse brine throughout much of the core length. Core 6 also exhibited brine within blue ice near the bottom of the core. Most of the cores consisted of new snow and firn in the upper several meters, except for Core 5 which was drilled into $2 \mathrm{~cm}$ of fresh snow and then bare ice (i.e. no firn layer), and Core 6 which contained no snow cover and was drilled in a blue ice region. Thin layers of dust, typically consisting of fine particle sizes were found in all but two of the melted cores (Cores 2 and 3). Core 4 exhibited the most dust deposition events as indicated by individual layers, as well as bands with the highest concentration of dust. All cores except Cores 2 and 3 also show indications of melt as either clear, bubble free ice layers detected within the firn which indicate melt percolation and saturation of firn layers, or very clear melt layers which contain bubbly ice as indicators of melt and refreeze.

Table 1. Firn and ice core properties

\begin{tabular}{|c|c|c|c|c|c|c|}
\hline Core \# & Latitude & Longitude & $\begin{array}{l}\text { Length } \\
\mathrm{m}\end{array}$ & $\begin{array}{l}\text { Average density } \\
\mathrm{g} \mathrm{cm}^{-3}\end{array}$ & $\begin{array}{l}\text { Brine layer depth } \\
\text { m }\end{array}$ & $\begin{array}{c}\text { Maximum salinity } \\
\text { ppt }\end{array}$ \\
\hline Core 1 & -77.8343 & 166.8373 & 15.1 & 0.67 & 14.9 & 9.4 \\
\hline Core 2 & -77.8699 & 166.8679 & 7.6 & 0.55 & 6.4 & 1.0 \\
\hline Core 3 & -77.9071 & 166.7776 & 5.4 & 0.57 & 4.6 & 1.8 \\
\hline Core 4 & -77.9153 & 166.6636 & 6.9 & 0.60 & 6.4 & 21.1 \\
\hline Core 5 & -77.9063 & 166.4499 & 4.2 & 0.91 & 1.4 & 2.3 \\
\hline Core 6 & -77.9203 & 166.2299 & 6.2 & 0.75 & 5.4 & 0.7 \\
\hline
\end{tabular}

Note that core locations are shown in Figs 3 and 9. 

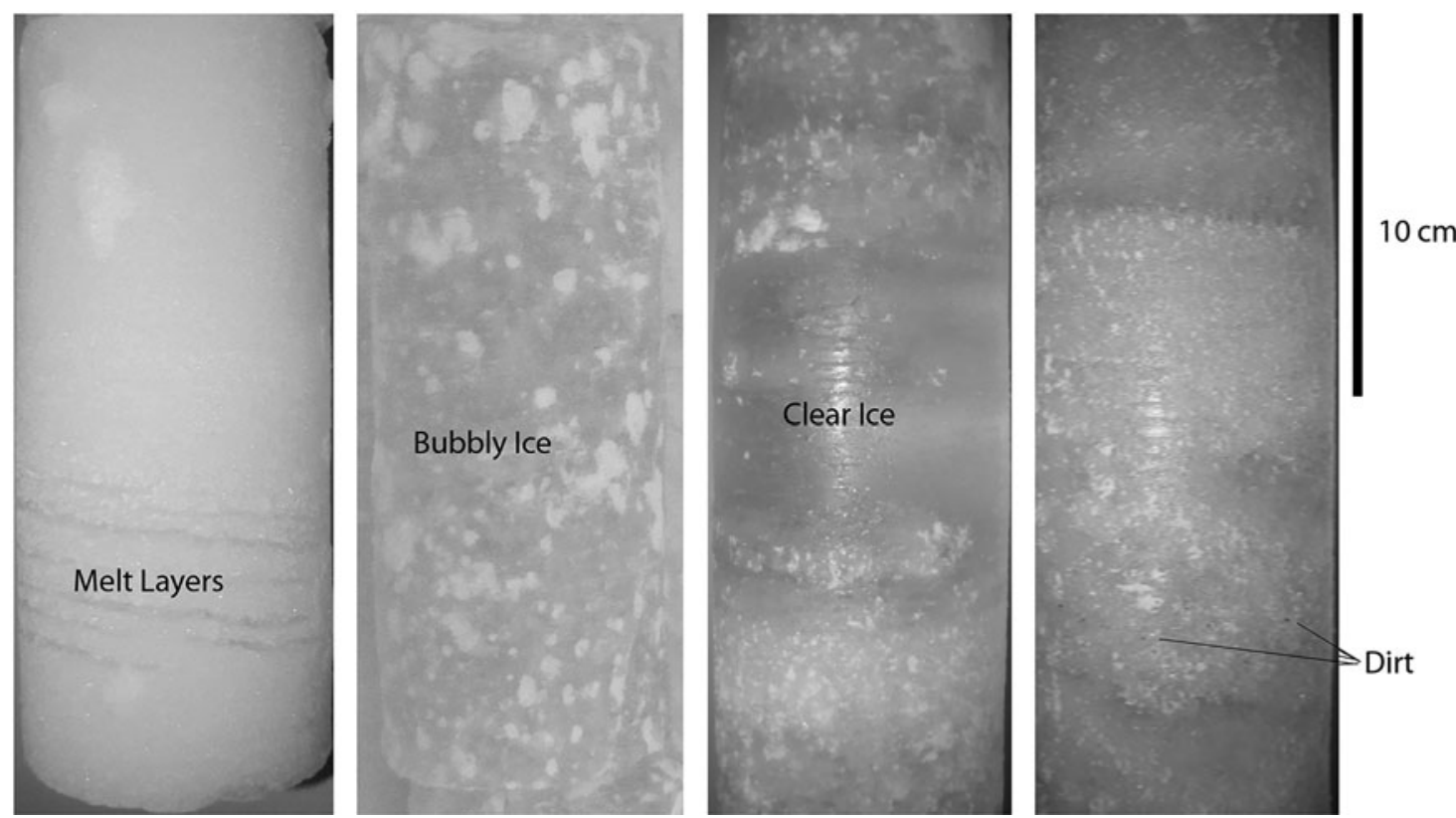

Fig. 4. Example of features (i.e. clear ice, bubbly ice, dust and melt layers) imaged in shallow ice and firn cores using near infrared (NIR) digital photography.

\section{Ice shelf}

The 400, 200 and $100 \mathrm{MHz}$ antennas each successfully imaged the meteoric ice bottom to a maximum of $165 \mathrm{~m}$ depth (1950 ns TWTT) where the longest profile we collected terminates in a region studied and discussed by Arcone and others (2016) known as the McMurdo shear zone (Figs 3 and 6). The $40 \mathrm{MHz}$ antenna, used only along Pegasus Road, did not penetrate through the brine horizon to successfully image the ice shelf bottom. Only two profiles, both using the $100 \mathrm{MHz}$ antenna, successfully penetrated to the bottom of

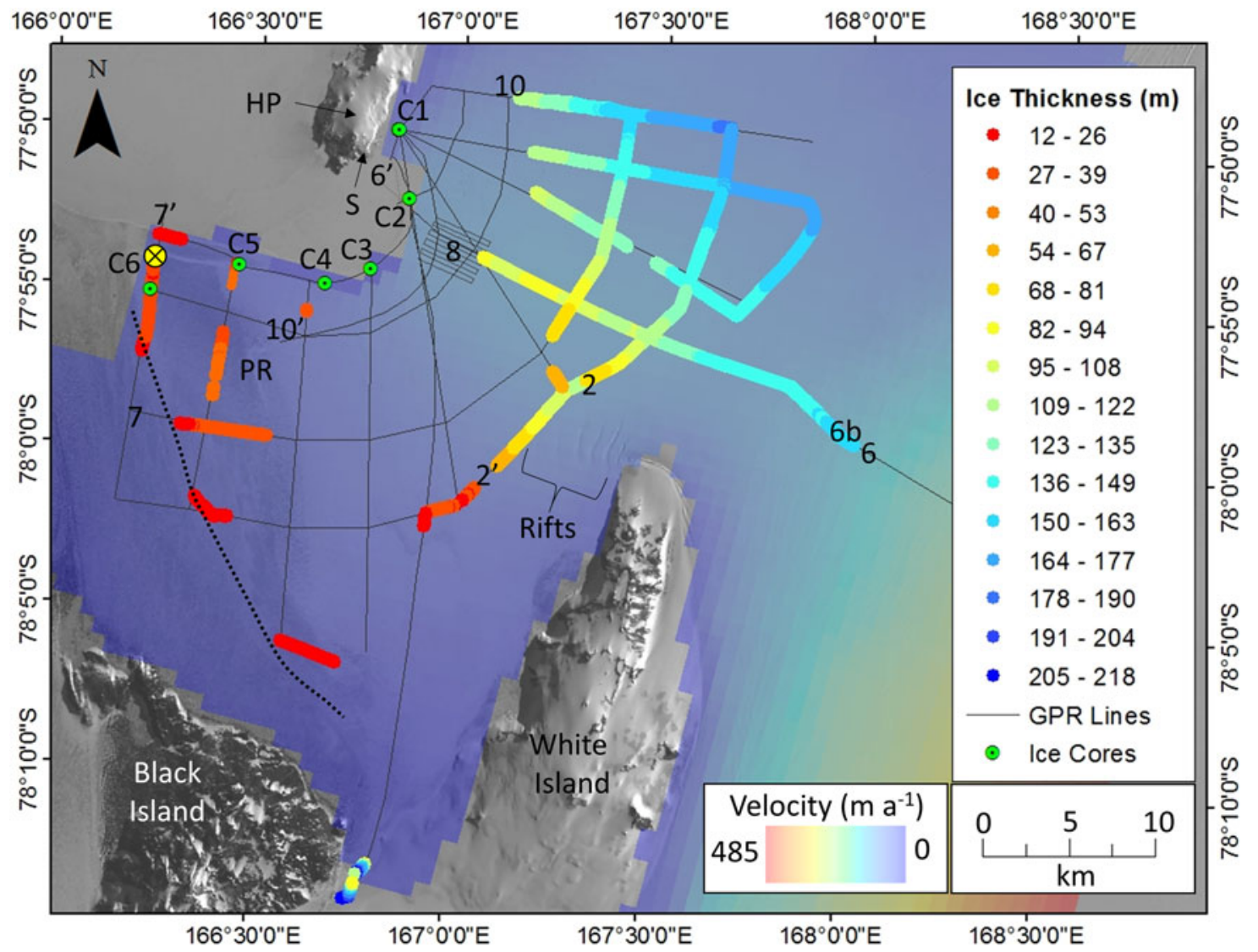

Fig. 5. Map with Landsat imagery showing meteoric ice thicknesses from GPR profiles collected during this study. Gray lines are approximate locations of all GPR profiles collected in the fall of 2015 and background color is from Quantarctica ice flow velocity dataset. Pegasus Runway (PG) core sites 1 through 6 (C1-C6), and rifts caused by White Island, are labeled. 


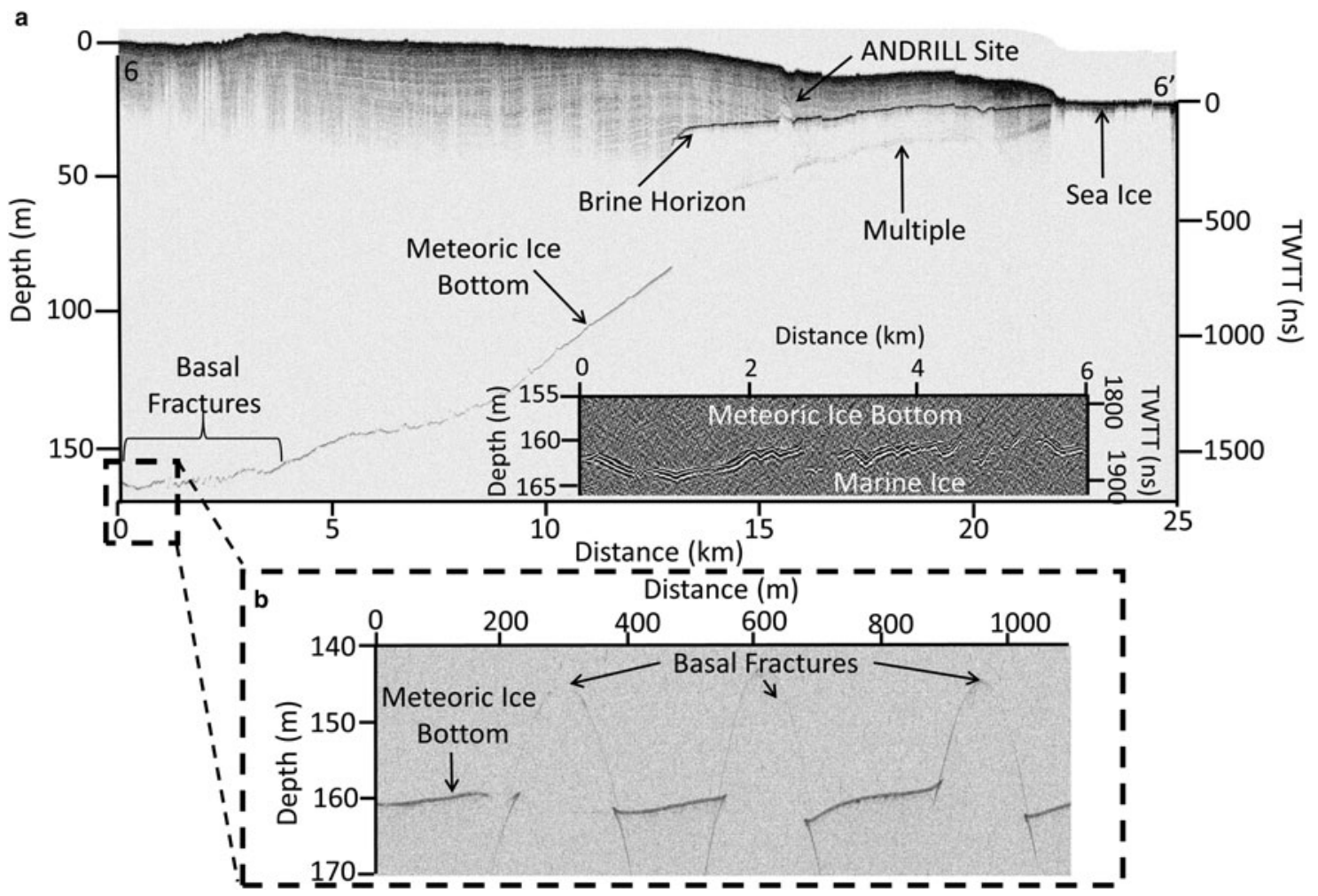

Fig. 6. $100 \mathrm{MHz}$ profile from the Shear Zone studied by Arcone and others (2016) to the ice shelf terminus near Scott Base. (a) full length $100 \mathrm{MHz}$ profile showing the meteoric ice bottom, masking of the ice shelf by the brine horizon, a brine horizon multiple and the ANDRILL site (discussed later in this paper). The inset figure in (a) shows meteoric ice over marine ice. (b) Zoom of the meteoric ice bottom in a $200 \mathrm{MHz}$ profile along the same transect shown in (a), showing subglacial fractures. The fractures are located north and slightly down-stream of White Island.

meteoric ice under the brine (Fig. 2). Ice thicknesses for these two profiles were highly variable, ranging between 20 and $60 \mathrm{~m}$ depth. Up-glacier of brine infiltration, the 100, 200 and $400 \mathrm{MHz}$ antennas each successfully imaged internal stratigraphy, the meteoric ice shelf base, and associated basal shelf fractures (Fig. 6). In unmigrated profiles, in which hyperbolas are more visible at depth versus migrated files, the basal fractures appeared as hyperbolas $\sim 20 \mathrm{~m}$ above the ice shelf bottom, suggesting that these fractures extend that far into the ice shelf base. Geometric spreading results in hyperbola footprints which mask the ice shelf base near each fracture. However, up-glacier results from Arcone and others (2016) suggest that these basal fractures are likely filled with marine ice and that tens of meters of freeze-on marine ice exists below the meteoric ice. The fractures appear to be consistently $\sim 120-140 \mathrm{~m}$ in width (Fig. 6b). The dimensions and geophysical signature of these fractures are similar to those expected and modeled as subglacial channels (e.g. Vaughan and others, 2012; Le Brocq and others, 2013; Sergienko, 2013); however, the ice flow dynamics of this region are well known (e.g. Glasser and others, 2006; Glasser and others, 2014; Arcone and others, 2016) and do not support a hypothesis of subglacial channels. Therefore, we interpret these features to represent rifts initially caused by the ice flow velocity gradient near White Island, which have been re-sutured within McMurdo Sound.

The MIS exhibits a marked transition with the convergence of ice originating from near White Island and ice originating from Black Island and Brown Peninsula (Fig. 7a). The convergence of these two flows occurs within the ablation zone of the MIS. Ice originating from the Brown Peninsula region shows significant stratification, whereas ice originating from between Ross and White Islands shows minimal or diffuse stratification. We interpret the stratified layers within the Brown Peninsula ice to be representative of entrained sediment or dust deposits originating from Black Island, Mina Bluff, or Brown Peninsula. The unconformity between these two ice units is consistent and unmistakable in multiple profiles which crossed into this southern ablation region of MIS.

Two large-scale features exist on the ice shelf, which should be monitored for future changes. The first is a $10 \mathrm{~km}$ long rift located $\sim 1 \mathrm{~km}$ upstream, oriented parallel to the ice shelf edge, and located $4 \mathrm{~km}$ northwest and downstream of Pegasus Runway. GPR profiles show a 75-100 m wide discontinuity in the brine horizon at $24 \mathrm{~m}$ depth, a velocity pull-up in the radar profile as manifest by the upward curling tails on either side of the discontinuity, and a lack of stratigraphy within the rift zone as shallow as $5 \mathrm{~m}$ depth, suggesting that sea water cuts across and above the brine horizon, potentially filling a large void where the rift is located (see Fig. 7b, near $10.2 \mathrm{~km}$ ). The velocity pull-up is due to the difference in radio wave velocity between firn $\left( \pm 0.173 \mathrm{~m} \mathrm{~ns}^{-1}\right)$ and the water-filled rift $\left(0.034 \mathrm{~m} \mathrm{~ns}^{-1}\right)$; the velocity contrast causes features to appear at different depths in the profile, which is not the actual case. We interpret this feature to be a bottom fracture that has propagated to near the surface. A second site located 1-2 km up-glacier of Pegasus Road along the SPOT traverse route shows similar features to the rift. A GPR grid revealed that the oblate feature is $600 \mathrm{~m} \times 1000 \mathrm{~m}$ in dimension and depressed 


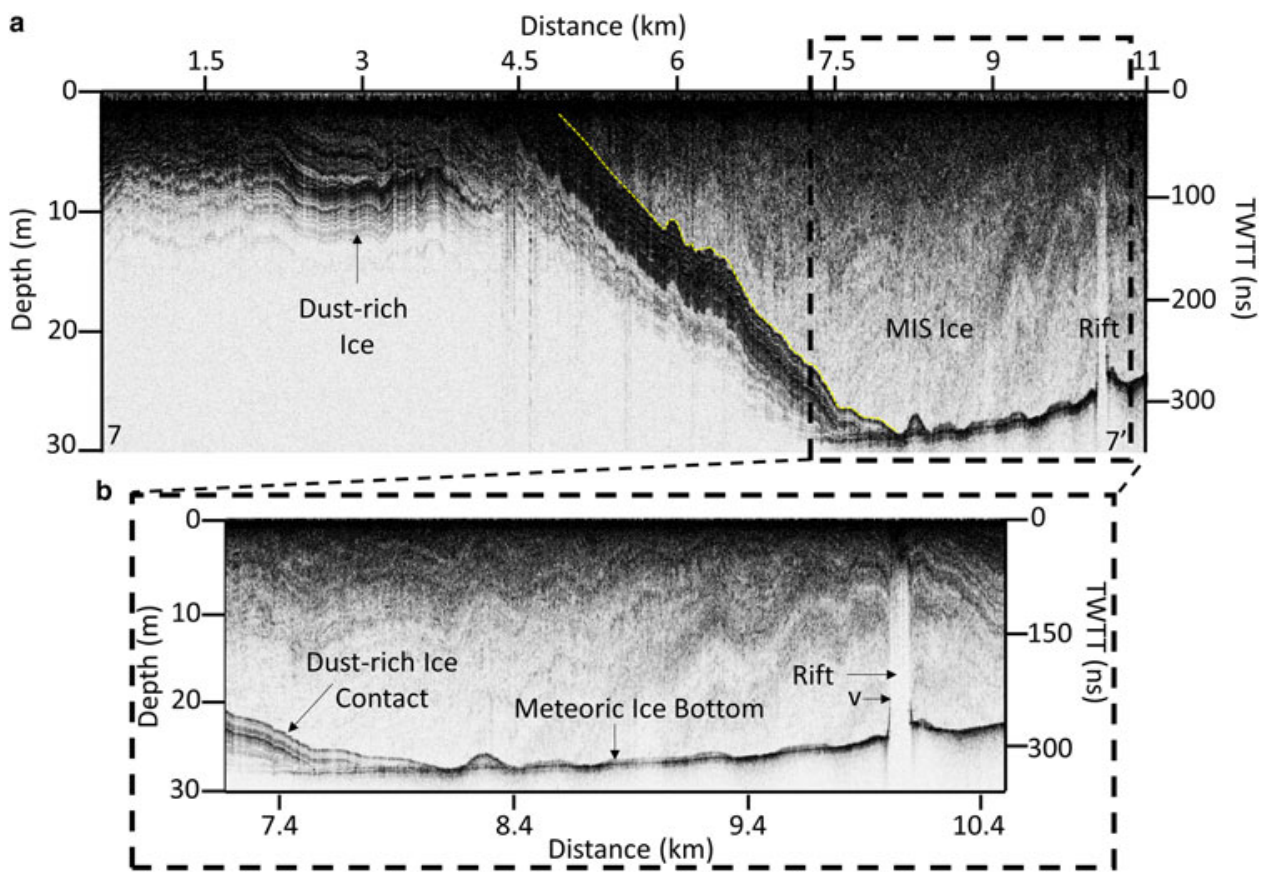

Fig. 7. (a) $100 \mathrm{MHz}$ GPR profile showing dust-rich ice originating from Black Island and Brown Peninsula region under MIS ice with a rift located near the ice shelf front. (b) Zoom of the dust rich ice and MIS contact also showing the velocity uplift (v) near the rift and meteoric ice bottom.

from the surrounding topography by $\sim 5 \mathrm{~m}$. The structure is capped by a hyperbolic reflection at $10 \mathrm{~m}$ depth, lacks any fine firn stratigraphy within and truncates stratigraphic horizons to the north and south between 10 and $20 \mathrm{~m}$ depth (Fig. 8). The bottom of this feature is defined by the surrounding brine horizon which is either discontinuous across the feature or reduced in reflection return power within the feature. We interpret this feature as the remains of the prior ANDRILL deep sediment drilling site which was established in 2006, based on available prior ANDRILL coordinates, local ice flow velocities placing the drill site now in this location, and the estimated footprint of the ANDRILL establishment. Note that ANDRILL appears to have acted as a pinning point on the shelf by reducing tidal flexure upglacier and causing folding of the ice immediately downglacier of the borehole site. We propose that hot-water drilling to maintain an open hole at ANDRILL acted similar to surface meltwater percolating within a temperate snowpack; that is, stratigraphic horizons in the GPR record caused by chemistry or density contrasts were disturbed from the introduced water, thereby diffusing horizons and associated stratigraphy within radar profiles. The result is an apparent unconformity between the surface conformable stratigraphy surrounding ANDRILL and a lack of finer stratigraphy within the ANDRILL region. A few faint, yet diffuse horizons are visible within the ANDRILL site which we interpret to be a diffuse saline brine horizon, and perhaps a shallower thick dusty horizon, which resisted diffusion from the introduced hot water. Diffusion of chemistry within snow and firn caused by melt, and an associated lack of stratigraphy or more diffuse horizons imaged in radar profiles are well-documented phenomena (e.g. Campbell and others, 2012).

\section{Brine}

Previous studies have suggested various mechanisms for ice shelf brine infiltration, including upward percolation of

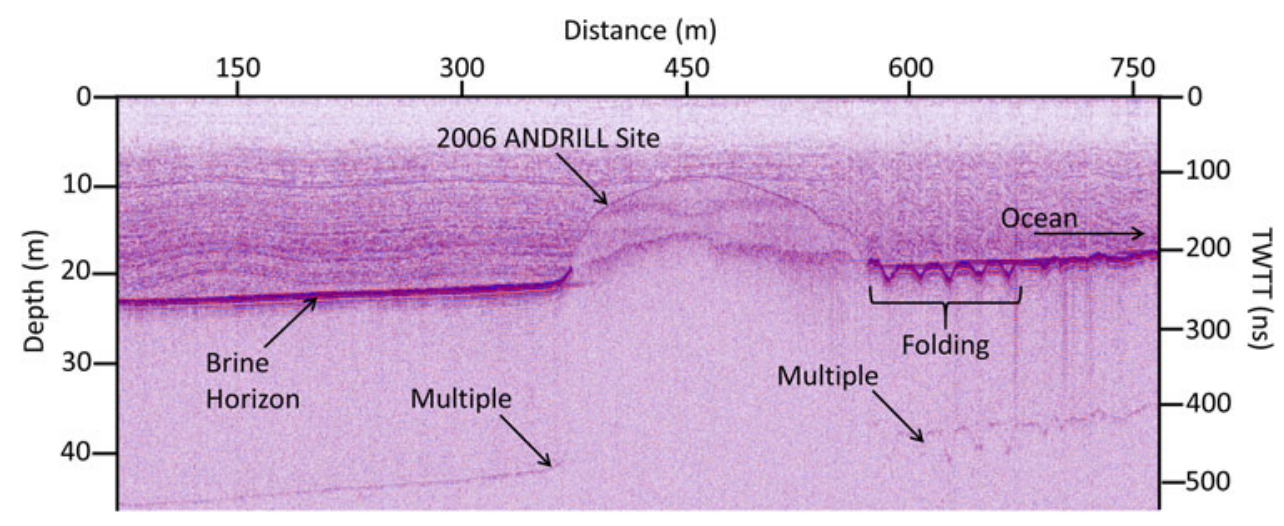

Fig. 8. $400 \mathrm{MHz}$ GPR profile showing the impact of the ANDRILL drilling site on MIS. Note the unconformity between the surface conformable stratigraphy and the ANDRILL site, which has only two prominent horizons, likely caused by the influence of hot water drilling activities. Also, note the significant folding located down-glacier of ANDRILL, which reaches to within $5 \mathrm{~m}$ of the ice shelf surface. 


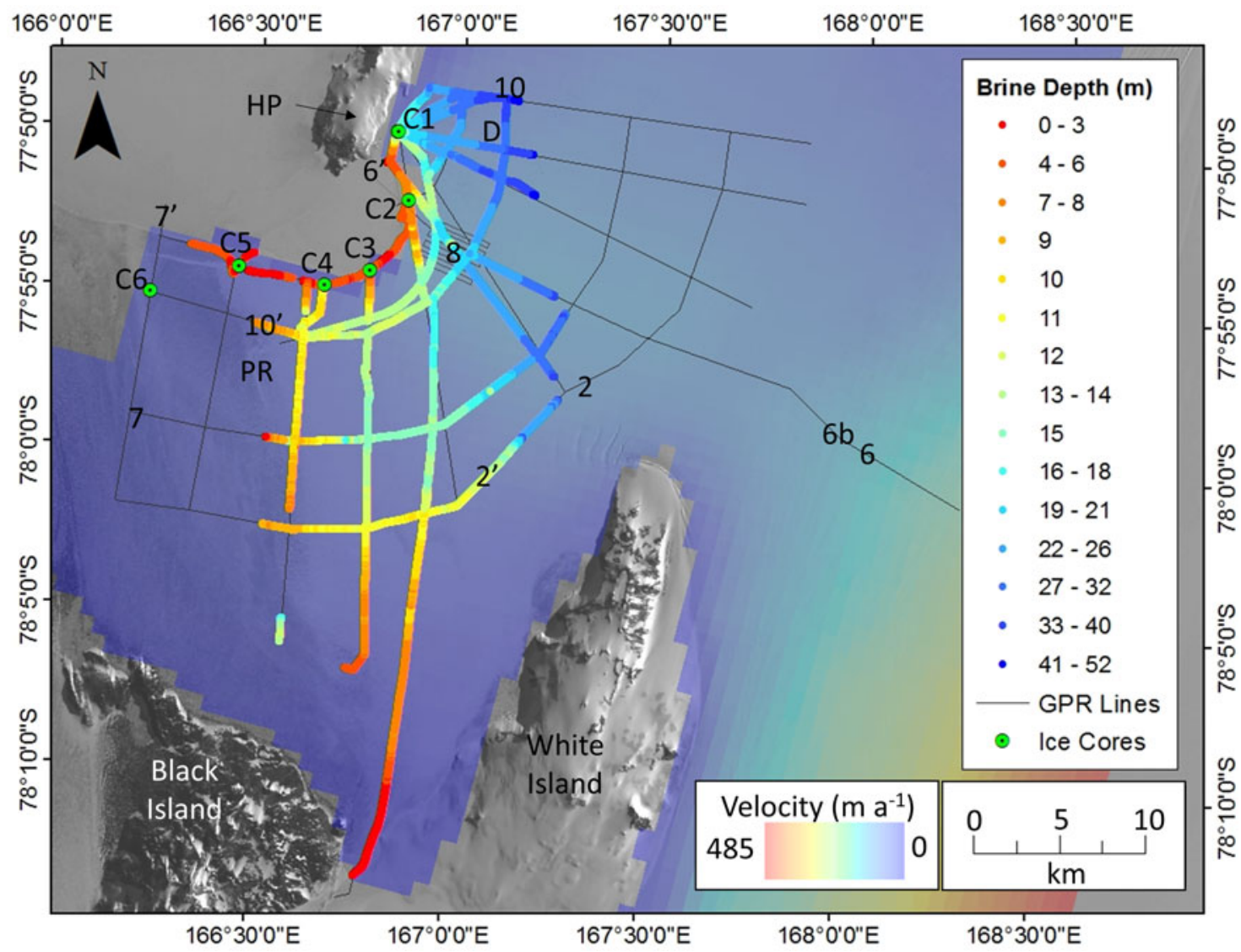

Fig. 9. Map with Landsat imagery showing the depth to brine from GPR profiles collected during this study. Gray lines are approximate locations of all GPR profiles collected in the fall of 2015 and background color is from Quantarctica ice flow velocity dataset. Core sites 1 through 6 are also labeled (C1-C6). The region where dissolution was observed by Kovacs and others (1982a, b) and Grima and others (2016) is labeled D.

seawater through basal tensile cracks, upward diffusion at ice crystal boundaries and lateral infiltration at the ice shelf front (Kovacs and Gow, 1975; Kovacs and others, 1982a). Periodic lateral infiltration at the ice shelf front is considered the primary mechanism of brine infiltration into the MIS (Kovacs and others, 1982b). Evidence in support of this mechanism comes from the observation of large fractures within the MIS brine horizon that represent former, wavelike intrusions of periodic packets of sea water that originated at the ice front after a large calving event (Kovacs and others, 1982a; Cragin and others, 1983). In describing the termination of brine infiltration, Kovacs and others (1982b) invoke an equation for brine flow velocity $u$ introduced by Thomas (1975):

$$
u=\frac{B_{0}}{\eta} \frac{\partial P}{\partial x}
$$

where $B_{0}$ is the specific permeability of firn, $\eta$ is the dynamic viscosity of brine fluid and $\partial p / \partial x$ approximates the pressure gradient over the brine layer. Eqn (1) shows that brine flow velocity is directly proportional to the specific permeability of firn; hence, brine infiltration terminates when firn permeability is zero. This impermeability is reached at the firn/ice transition zone when firn density reaches $0.82 \mathrm{~g} \mathrm{~cm}^{-3}$ (Kovacs and Gow, 1975). However, evidence of slow continued brine migration has been observed in the MIS, deeper than the firn/ice transition zone (Kovacs and others, 1982a; Grima and others, 2016). In this region, concentrated brine continues to gradually percolate inland into deeper and warmer sections of the ice shelf through the dissolution of the surrounding ice (Fig. 9, noted by D).

The MIS brine horizon extends over $700 \mathrm{~km}^{2}$ in area and is constrained by White and Black Island to the South and Ross Island and McMurdo Sound to the North (Fig. 9). Our results show that the horizon penetrates nearly $20 \mathrm{~km}$ upglacier and ranges between $\sim 5$ and $52 \mathrm{~m}(\sim 70-460 \mathrm{~ns}$ TWTT) in depth, from the ice shelf front moving up-glacier. Other studies show similar results (Heine, 1968; Kovacs and Gow, 1975; Kovacs and others, 1982a). Profiles collected parallel to the ice shelf front reveal that the horizon undulates up to $10 \mathrm{~m}$ in depth over relatively short distances ( 100-200 m).

Several discontinuities or fractures exist within the brine, which are similar to those imaged in prior studies (e.g. Kovacs and Gow, 1975; Kovacs and others, 1982a, b; Morse and Waddington, 1994; Grima and others, 2016). These 'steps' (as termed by prior authors) vary in size from sub-meter to several meters tall and have been observed within the brine horizon as well as at the most distal upglacier extent of the horizon. Small, closely spaced steps typically characterize the inland termination of a brine horizon (e.g. Fig. 2), while larger steps may depict former calving events, fracturing, or rifting (Kovacs and others, 1982a).

\section{Englacial structure}

GPR profiles reveal a combination of surface conformable stratigraphy (SCS) in which snow and firn layering is 


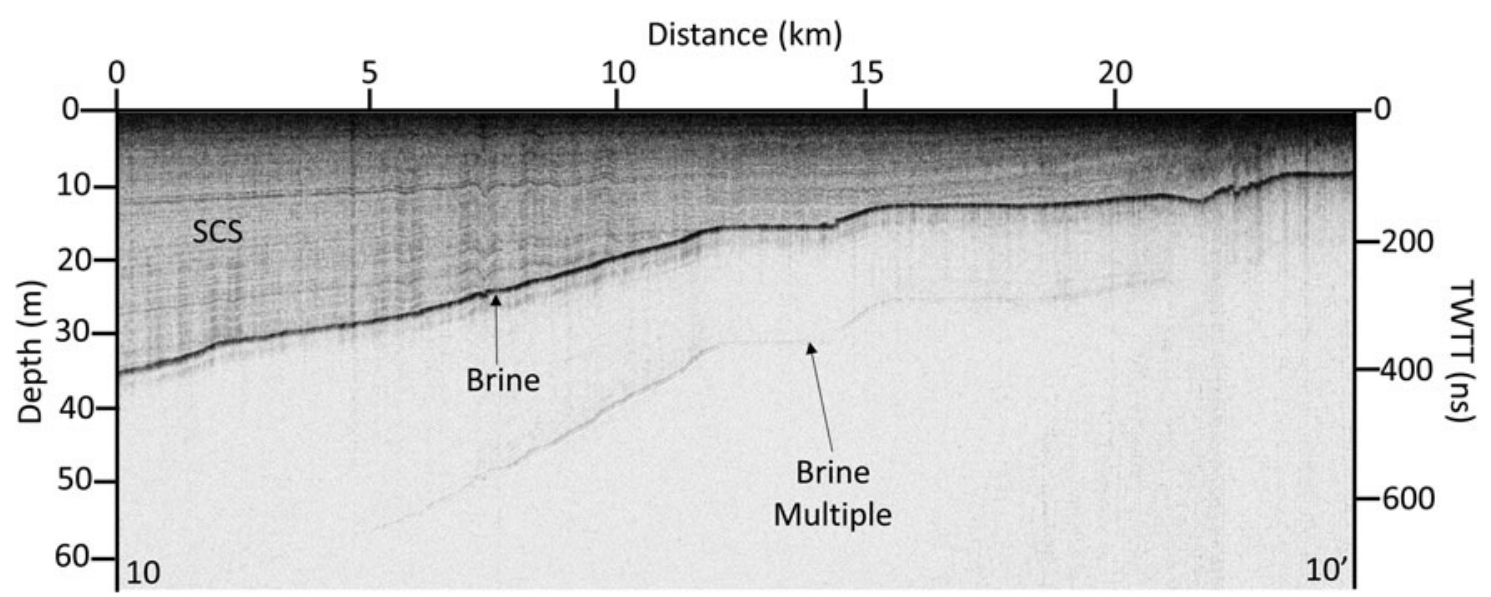

Fig. 10. $400 \mathrm{MHz}$ GPR profile oriented north to south and parallel to the ice shelf front showing the significant thinning of surface conformable stratigraphy (SCS) toward the south.

continuous and directly related to depositional processes with no discontinuities, and complex englacial structures or unconformities across the ice shelf. The 400, 200 and 100 $\mathrm{MHz}$ antennas displayed maximum depths of SCS to 40, 50 and $80 \mathrm{~m}$, respectively, when profiling regions of MIS. The systems used for this effort have provided similar results in prior studies (e.g. Campbell and others 2012). Stratigraphy over the brine thickens from Pegasus Runway toward Ross Island (North) (Fig. 10); immediately south of Pegasus Runway, the snow and firn transitions to a blue ice ablation surface, which persists to the edge of Black Island. This pattern corresponds well with the higher accumulation rates near Ross Island relative to Black Island as noted by Grima and others (2016). We attribute thicker SCS toward Ross Island in large part to katabatic winds originating inland that blow snow past the White Island region. These winds also scour the glacial-ice area and redeposit snow near Ross Island because it acts as a natural topographic block (e.g. Seefeldt and others, 2003). Profiles collected perpendicular to the shelf edge also reveal gradual thickening of the snow and firn above the brine in a direction distal to the ice shelf front (e.g. Figs 3 and 6). Most profiles show the brine truncates or cross-cuts numerous stratigraphic horizons which suggest that the brine was formed after the horizons and more importantly, that the porous firn structure acts as little hindrance to lateral brine infiltration.

Although we do not have density measurements along each of our profiles, Grima and others (2016) show that firn with densities between 0.73 and $0.83 \mathrm{~g} \mathrm{~cm}^{-3}$ act as a boundary to brine infiltration. We propose that our ground-based radar can be combined with findings from Grima and others (2016) to provide high-resolution information about density and permeability of the ice shelf, based on the imaged lateral extent and depth of brine. When combined with other recent results regarding thicknesses of deeper meteoric and marine ice imaged by GPR (e.g. Arcone and others, 2016) and broader MIS history (e.g. Glasser and others, 2014), a highly-detailed physical model of MIS, relative to other shelves in Antarctica, could be constructed. This physical model would be useful for answering numerous questions related to englacial influences on ice flow dynamics. A direct comparison of our data with other datasets collected across MIS (e.g. Kovacs and others, 1982a, b; Morse and Waddington, 1994; Grima and others, 2016), would be a reasonable first step toward creating such a model. A critical missing piece, as eluded by Arcone and others (2016) (and one we were also unable to resolve) is an estimate of the lateral extent and thickness of marine ice across MIS. Like Arcone and others (2016), we propose lower frequency $(10-40 \mathrm{MHz})$ radar profiling to image full thickness of the marine ice in areas where the brine does not infiltrate.

Near the transition zone next to Scott Base (Fig. 11a), a GPR profile collected slightly oblique to the ice shelf edge reveals a distinct series of synclinal and anticlinal folds within the englacial structure down to $15 \mathrm{~m}$ depth and extending $\sim 2 \mathrm{~km}$ up-glacier (Fig. 11b). Fold dips are steeper at depth and appear as cross-cut unconformities at the surface. These folds result from compression as the ice shelf flows around White Island and impacts Hut Point Peninsula on Ross Island. Valley glacier ice flowing off Hut Point Peninsula also likely influences the ice shelf as it flows toward the ice shelf edge. We interpret the synclinal folds to be filled with winter snow accumulation, which likely melts each late summer season, creating the unconformity at the surface. Melt ponds form each year in the synclinal depressions to the north of this GPR profile within the transition zone (Fig. 11a) suggesting that much of the folded structure in this area consists of non-permeable blue ice. However, the brine horizon can be traced from $\sim 0$ to $180 \mathrm{~ns}$ TWTT depth originating at the ice shelf-sea/ice transition $(\sim 0-17 \mathrm{~m}$ assuming the approximate value of $\varepsilon$ for dry firn is 2.2). The brine creates an unconformity relative to the folded stratigraphy, suggesting that the folds are both permeable (i.e. likely firn) and that it is not a hindrance to lateral brine infiltration. It is also possible that the brine in this area diffuses through layers as suggested by Kovacs and others (1982a). Regardless of the mechanism for brine infiltration, it is obvious from the GPR and visible observations that the density and stratigraphy of the transition zone are intricate, and would therefore require a more detailed survey to determine these structural complexities.

\section{Dynamic signals: fractures, suture blocks, folds and rifts}

Ice shelf fracturing and re-suturing of these blocks has occurred from expansion and compression as ice flows around White Island into McMurdo Sound. These features 
a
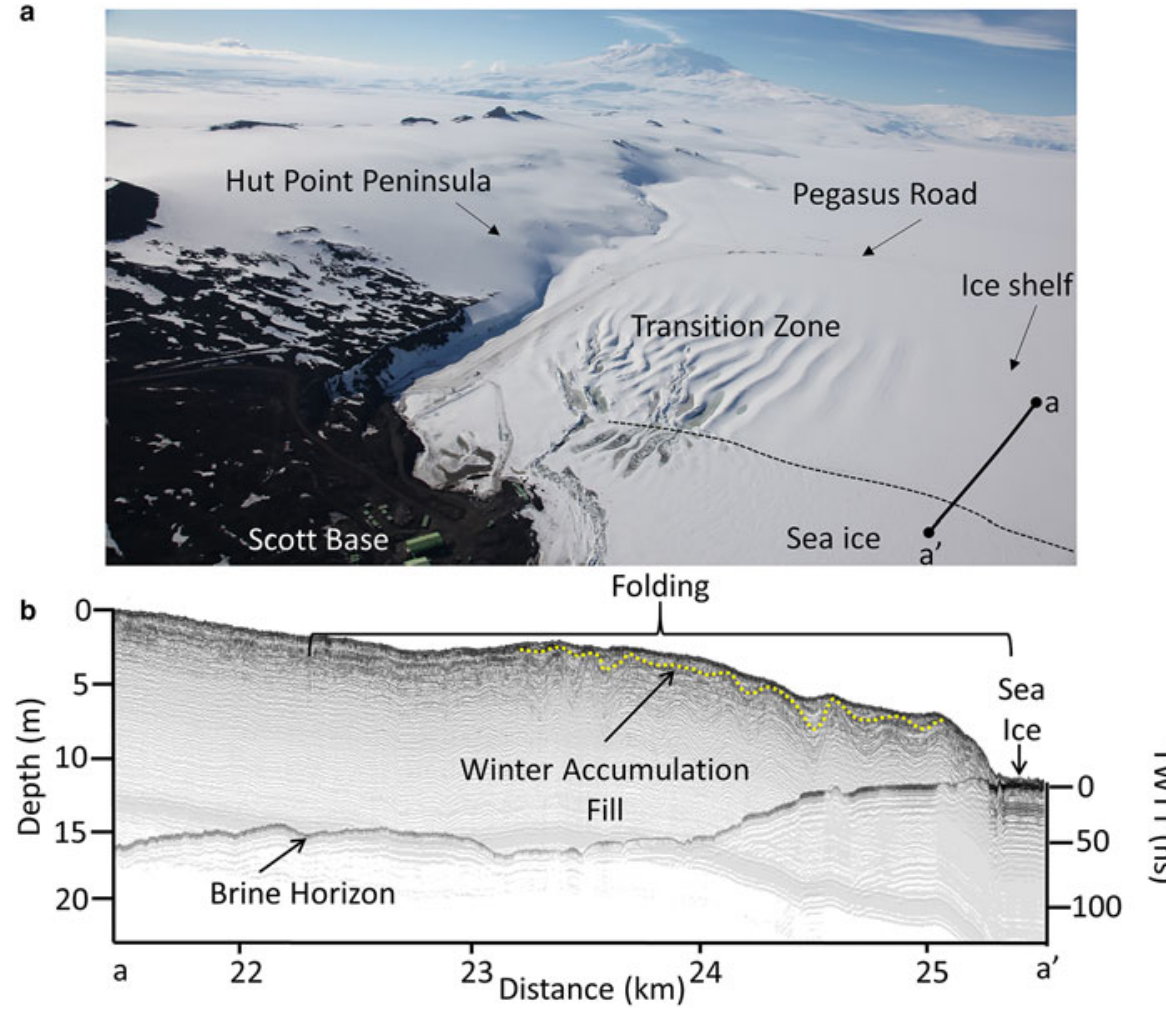

\section{先}

Fig. 11. (a) Aerial Photo showing the Transition Zone located near Scott Base with major features labeled including approximate ice flow directions (arrows). Note the melt ponds situated within the synclinal folds of the transition zone and the approximate location of (b) denoted by a and a' (Photo courtesy of Ben Roth) (b) $100 \mathrm{MHz}$ GPR profile showing folds near the transition zone, which are cross-cut by the brine horizon. Also, note the approximate location of the winter accumulation filling in the synclinal portion of each fold.

are obvious both in satellite imagery as seen in Fig. 3, and in GPR profiles collected near White Island. Within an ice shelf, basal crevasses (e.g. Fig. 6b) can propagate up through the ice by gradual upward penetration of sea water, and can theoretically reach up to $78 \%$ of the thickness of the ice shelf (Weertman, 1980). Surface crevasses or rifts (e.g. Fig. 3) can propagate downwards in regions where a sufficient flux of meltwater exists on the surface of the ice sheet (Fastook and Schmidt, 1982). Basal and surface crevasses located in close proximity to one another can become conjoined and form full fractures that extend the entire thickness of the ice shelf. Full fractures could significantly destabilize the MIS and put it at risk of increased calving activity and eventual break-up. Fortunately, no continuous feature exists within the ice shelf proper to suggest any instability. Likewise, surface crevasses appear stable based on SCS located within all major surface fractures noted in GPR profiles, and basal fractures appear to propagate only $10-15 \%$ of the total ice shelf thickness suggesting that sea water has not yet significantly influenced these fractures or that ice shelf compression plays the dominant role in these regions.

The folds which occur down-glacier of the ANDRILL site (Fig. 8) suggest how little a surface impact needs to be to alter local ice shelf dynamics. This said, results from this study suggest that MIS is stable for the time being. If surface or basal melting increases during the coming years, the stability of MIS could change (e.g. Scambos and others, 2000; Alley and others, 2016). Results from this and other recent studies (e.g. Arcone and others, 2016; Grima and others, 2016) provide a baseline to compare with if future changes to MIS occur, namely at the transition zone, ice shelf rift near the front of the MIS, subglacial suture zones, or basal fractures northwest of White Island.

\section{CONCLUSIONS}

GPR surveys successfully mapped the MIS meteoric ice shelf thickness, the extent, depth and continuity of the brine horizon, and englacial stratigraphy, unconformities, or discontinuities. In most places where brine was buried beneath the surface, the radar response was attenuated enough to preclude imaging meteoric ice below. Penetration through the brine was successful on profiles collected distal from the ice shelf front, suggesting a salinity gradient of the brine which supports earlier studies. Several basal ice shelf fractures and brine discontinuities existed, which can mostly be explained by ice flow dynamics. Broader results from this study suggest that MIS currently exhibits no signs of instability. However, multiple locations are recommended for long-term monitoring, including an existing rift located near the MIS terminus and the ANDRILL site, which shows that anthropogenic activity can physically influence ice shelf dynamics, at least on a local scale. Future high spatial-resolution radar studies and ice coring could be completed at these two locations to confirm internal structure of these features.

\section{ACKNOWLEDGEMENTS}

This study was conducted for the National Science Foundation through Inter Agency Agreement Number, 1564557. Seth Campbell was the Principal Investigator. Zoe Courville and Sally Shoop were co-investigators. Zoe Courville and Seth Campbell conducted the field work with field assistance 
provided by Stephen Zellerhoff, Marie McLane, Paul Koubek, Jonathan White, Laura Gerwin, Michael Pfalmer, and Ester Babcock. Samantha Sinclair and Joel Wilner assisted with data processing, analysis and writing. We appreciate help from the Polar Geospatial Center for providing GIS mapping support, the Norwegian Polar Institute for providing the Quantarctica datasets, and UNAVCO for providing GPS support. We also appreciate Lockheed and associated subcontractors for providing logistical support, specifically Ryan Wallace, Baija Sass, Tony Buchannan, Meghan Parks, Bev Walker, and John Loomis. Bernd Kulessa, Cyril Grima, and an anonymous reviewer provided many helpful and insightful comments in the manuscript preparation.

\section{CONTRIBUTION STATEMENT}

Campbell wrote most of this paper. Courville added text regarding firn and ice cores. Wilner added text regarding brine formation, and edits were provided by Sinclair, Wilner and Courville. Campbell processed all GPR profiles, Courville processed all core samples, and Sinclair, Wilner and Campbell picked meteoric ice bottom and brine horizons from radar data.

\section{REFERENCES}

Alley KE, Scambos TA, Siegfried MR and Fricker HA (2016) Impacts of warm water on Antarctic ice shelf stability through basal channel formation. Nat. Geosci., 9, 290-293

Arcone SA (1996) High resolution of glacial ice stratigraphy: a ground-penetrating radar study of Pegasus Runway, McMurdo Station, Antarctica. Geophysics, 61(6), 1653-1663

Arcone SA, Delaney AJ and Tobiasson W (1994) Subsurface radar investigations at the Pegasis Glacial-Ice Runway and Williams Field, McMurdo Station, Antarctica. CRREL Rep., 94-12, 23

Arcone SA and 5 others (2016) Ground-penetrating radar profiles of the McMurdo Shear Zone, Antarctica, acquired with an unmanned rover: interpretation of crevasses, fractures, and folds within firn and marine ice. Geophysics, 81(1), WA21-WA34

BRP (Blue Ribbon Panel) (2012) More and better science in Antarctica through increased logistical effectiveness. Report of the U.S. Antarctic Program Blue Ribbon Panel, Washington, D.C., 232 p.

Campbell S and 7 others 2012. Melt regimes, internal stratigraphy, flow dynamics, and glaciochemistry of three glaciers in the Alaska Range. J. Glaciol. 58(207), 99-109. DOI: 10.3189/ 2012JoG10J238

Clough JW (1973) Radio echo sounding: brine percolation layer. J. Glaciol., 12(64), 141-143

Cragin JH, Gow AJ and Kovacs A (1983) Chemical fractionation of brine in the McMurdo Ice Shelf, Antarctica. CRREL Rep., 83-86

Fastook JL and Schmidt WF (1982) Finite element analysis of calving from ice fronts. Ann. Glaciol., 3, 103-106

Gelatt TS and 5 others (2010) History and fate of a small isolated population of Weddell seals at White Island, Antarctica. Conservation Genetics, 11, 721-35

Glasser NF, Goodsell B, Copland L and Lawson W (2006) Debris characteristics and ice-shelf dynamics in the ablation region of the McMurdo Ice Shelf, Antarctica. J. Glaciol., 52(177), 223-234

Glasser NF, Holt T, Fleming E and Stevenson C (2014) Ice shelf history determined from deformation styles in surface debris. Antarct. Sci., 26(6), 661-673
Grima CJ and 6 others (2016) Radar detection of the brine extent at McMurdo Ice Shelf, Antarctica, and its control by snow accumulation. Geophys. Res. Lett., 43, 1-8

Heine AJ (1968) Brine in the McMurdo Ice Shelf, Antarctica. N. Z. J. Geol. Geophys., 11(4), 829-839

Joughin I, Smith B and Medley B (2014) Marine ice sheet collapse potentially underway for Thwaites Glacier Basin, West Antarctica. Science, 344, 735-738

Klokov V and Diemand D (1995) Glaciology of the McMurdo Ice Shelf in the area of air operations. Contrib. Antarct. Res. IV, Antarct. Res. Ser., 67, 175-195

Kovacs A and Gow AJ (1975) Brine infiltration in the McMurdo Ice Shelf, McMurdo Sound, Antarctica. J Geophys. Res., 80(15), 1957-1961

Kovacs A, Gow AJ and Cragin JH (1982a) The brine zone in the McMurdo Ice Shelf, Antarctica. Ann. Glaciol., 3, 166-171

Kovacs A, Gow AJ, Cragin JH and Morey RM (1982b) The brine zone in the McMurdo Ice Shelf, Antarctica. CRREL Rep., 82-39, 28

Kovacs A, Gow AJ and Morey RM (1993) A reassessment of the insitu dielectric constant of polar firn. CRREL Rep. 93-26, 23

Le Brocq AM and 10 others (2013) Evidence from ice shelves for channelized meltwater flow beneath the Antarctic Ice Sheet. Nat. Geosci., 6, 945-948

Luckman A and 5 others (2012) Basal crevasses in Larsen C Ice Shelf and implications for their global abundance. Cryosphere, 6, 113-123

Morey RM and Kovacs A (1982) The effects of conductivity on highresolution impulse radar sounding, Ross Ice Shelf, Antarctica. CRREL Rep., 82-42, 12

Morse DL and Waddington ED (1994) Recent survey of brine infiltration in McMurdo Ice Shelf, Antarctica. Ann. Glaciol., 20, 215-218

Paige RA (1968) Sub-Surface melt pools in the McMurdo Ice Shelf, Antarctica. J. Glaciol., 7(51), 511-516

Rignot E, Mouginot J, Morlighem M, Seroussi H and Scheuchl B (2014) Widespread rapid grounding line retreat of Pine Island, Thwaites, Smith, and Kohler glaciers, West Antarctica, from 1992 to 2011. Geophys. Res Lett., 41, 3502-3509

Scambos TA, Hulbe C, Fahnestock M and Bohlander J (2000) The link between climate warming and break-up of ice shelves in the Antarctic Peninsula. J. Glaciol., 46(154), 516-530

Scambos TA, Bohlander JA, Shuman CA and Skvarca P (2004) Glacier acceleration and thinning after ice shelf collapse in the Larsen B embayment, Antarctica. Geophys. Res. Lett., 31(18), L18402

Seefeldt MW, Tripoli GJ and Stearns CR (2003) A high-resolution numerical simulation of the wind flow in the Ross Island region, Antarctica. Mon. Weather Rev., 131, 435-458

Sergienko OV (2013) Basal channels on ice shelves. J Geophys. Res., 118, $1-14$

Sergienko OV and Hulbe CL (2011) 'Sticky spots' and subglacial lakes under ice streams of the Siple Coast, Antarctica. Ann. Glaciol., 52(58), 18-22

Shoop S, Knuth M and Wieder W (2013) Measuring vehicle impacts on snow roads. J. Terramech., 50(1), 63-71

Stuart AW and Bull C (1963) Glaciological observations on the Ross Ice Shelf near Scott Base, Antarctica. J. Glaciol., 4(34), 399-414

Thomas RH (1975) Liquid brine in ice shelves. J. Glaciol., 14(70), 125-136

Vaughan DG and 8 others (2012) Subglacial melt channels and fractures in the floating part of Pine Island Glacier, Antarctica. J. Geophys. Res., 117(F03012), 1-10

Weertman J (1980) Bottom crevasses. J. Glaciol., 25(91), 185-188

Woodward J and Burke MJ (2007) Applications of ground-penetrating radar to glacial and frozen materials. J. Environ. Eng. Geophys., 12(1), 69-85 